\title{
Relationship between admission criteria and academic performance: A correlational study in nursing students
}

\author{
Imran Inayat Yousafzai' ${ }^{1}$ Brekhna Jamil²
}

\begin{abstract}
Background \& Objective: An admission criterion is one of the key indicators of academic success. The purpose of admission process is to select best candidates for the particular program who will complete the program successfully. Thus rigorous admission criteria can predict academic performance, decrease failure rate and successful completion of degree. The objective of this study was to determine the relationship between various variables in the existing admission criteria and academic performance.

Methods: A cross sectional study design was chosen. Data (2009-2017) was gathered from the records of Institute of Nursing Science, Khyber Medical University. Variables in the admission criteria included age, gender, previous academic performance, entry test score and experience. The dependent variable was academic performance measured in CGPA. The data was analyzed using correlation and regression analysis through SPSS and STATA.

Results: The results reported a significant relationship between admission criteria and the academic performance of nursing students. Various variables in the admission criteria i.e. SSC marks ( $r=0.32$, $p=>0.001)$, previous academic score at diploma level $(r=0.48, p=>0.001)$ and entry test scores $(r=0.26$, $p=>0.001$ ) have significant relationship between academic performance. However, previous academic scores at diploma level were better predictors of the academic performance.

Conclusion: The study concludes to use integrated admission criteria for the selection of students and bring changes in the traditional admission process.
\end{abstract}

KEYWORDS: Admission criteria, Academic performance, Post RN, Nursing.

doi: https://doi.org/10.12669/pjms.35.3.217

How to cite this:

Yousafzai II, Jamil B. Relationship between admission criteria and academic performance: A correlational study in nursing students. Pak J Med Sci. 2019;35(3):858-861. doi: https://doi.org/10.12669/pjms.35.3.217

This is an Open Access article distributed under the terms of the Creative Commons Attribution License (http://creativecommons.org/licenses/by/3.0), which permits unrestricted use, distribution, and reproduction in any medium, provided the original work is properly cited.

1. Mr. Imran Inayat Yousafzai, BSN, MSPH, MHPE.

2. Dr. Brekhna Jamil, BDS, MPH, MHPE. Assistant Professor,

Institute of Health Professions Education \& Research,

1,2: Khyber Medical University,

Peshawar, Pakistan.

Correspondence:

Dr. Brekhna Jamil, Assistant Professor, Institute of Health Professions Education \& Research, Khyber Medical University, Peshawar, Pakistan.

Email: drbrekhna.iph@kmu.edu.pk

* Received for Publication:

December 18, 2018

* Revision Received:

* Revision Accepted:
March 6, 2019

March 12, 2019

\section{INTRODUCTION}

Admission criteria is one of the key indicators to predict academic performance. ${ }^{1}$ Educationists are interested in identifying key factors which can predict academic performance. Studies suggest that rigorous validated admission criteria can predict the decrease failure rate and lead to successful completion of program. ${ }^{2}$

Literature reviews suggests that admission criteria constitutes of cognitive and non-cognitive factors. ${ }^{3}$ Cognitive variables include aptitude tests, previous academic marks, admission tests, while non-cognitive factors includes gender, previous experience, age, race, personality and ethnicity. Various cognitive and non-cognitive factors are 
set in the admission criteria to identify and select students who can successfully complete their programs. ${ }^{4,5}$

Available evidence suggests that a better formulated admission criteria including mix of academic and non-academic factors can predict better academic performance. ${ }^{6}$ Admission criteria to diplomas and baccalaureate degree in nursing in Pakistan mainly consist of previous academic performance and entry tests score, age, gender and interviews. Admission criteria have not been researched to inform whether it is a strong predictor of academic performance. The purpose of this study was to assess the relationship between admission criteria and academic performance in the Post RN BSN nursing students at Khyber Medical University, Peshawar.

\section{METHODS}

A correlational study was conducted. A specifically designed Checklist was used to record the data from the available records on admission criteria and academic performance. The checklist includes the information about Marks in SSC, Previous academic Marks in General nursing and midwifery/speciality, Entry Test Marks, Academic performance in GPA. It was validated from the expert in the field of medical education and nursing education. The checklist was also field tested for errors before data collection. The records of all 197 Post RN nursing students enrolled and passed out between (2008-2017) in Khyber Medical University, Peshawar was reviewed using the checklist. Those who failed to complete the course due to any reason were not included in the study. Data was collected after ASRB and ethical approval from ethical review board of Khyber Medical University. Data regarding enrolment characteristics was collected from the students' personal files and admission records while data about academic performance in Post-RN Program were obtained from examination section of Khyber Medical University, Peshawar. The study variables included previous academic marks measured in percentage obtained in Matric (higher secondary school certificate), Nursing diploma, entry test marks, gender and age of the student at the time of admission. Outcome variable was academic performance that was measured in CGPA. Descriptive analysis was done on all 197 participants. Regression analysis, t-test and Pearson's correlation analysis were also done. Data analysis was carried out using SPSS version 22.0 and STATA.

\section{RESULTS}

Results showed that majority of the participants $86.3 \%(n=170)$ were females. The mean ages of the participants were $34.33+-$ SD5.66. This study shows a significant $(p<0.001)$ difference $(0.29)$ in the mean academic performance of males and females. This difference is statistically significant $(p>0.001)$ after using $\mathrm{t}$ test. Apart from this, a moderate relationship $(\mathrm{r}=0.32, \mathrm{p}<0.001)$ was observed between SSC marks and academic performance. A moderate relationship $(\mathrm{r}=0.48, \mathrm{p}<0.001)$ was also observed between the previous academic score and the academic performance. The results show a significant weak relationship between academic performance and entry test score $(\mathrm{r}=0.26$, $\mathrm{p}=<0.001)$ and also between age at the time of admission and the academic performance $(r=-0.15$, $\mathrm{p}=0.030$ ), besides weak non-significant negative relationship between years of experience and the academic performance of the nursing students $(\mathrm{r}=$ $-0.09, p=>0.18$ ). Table-I shows a detailed statistical analysis of correlation.

As shown in Table-II, regression analysis was done between the admission criteria and the academic performance. The predictor variables include gender, age at the time of admission, SSC marks, previous academic marks in nursing diploma, entry test score and years of experience whereas the dependent variable is academic performance measured in CGPA. The results of regression model shows that the previous academic score at diploma nursing level $(\beta=0.0327$, $\mathrm{p}<0.001)$, SSC marks $(\beta=0.0127, \mathrm{p}<0.001)$ and years of experience $(\beta=0.0237, p<0.011)$, entry test score $(\beta=0.005, p<0.002)$ were better predictor of academic performance in nursing students. However, age at

Table-I: Relationship of academic performance with variables of admission criteria using Pearson's correlation analysis ( $\mathrm{N}=197)$.

\begin{tabular}{lccccc}
\hline & $\begin{array}{c}\text { Age at the time } \\
\text { of admission }\end{array}$ & SSC Marks & $\begin{array}{c}\text { Previous academic score } \\
\text { in diploma nursing }\end{array}$ & $\begin{array}{c}\text { Entry Test } \\
\text { score }\end{array}$ & Experience \\
\hline Academic & $-0.1539^{*}$ & $0.3287^{*}$ & $0.4825^{*}$ & $0.2698^{*}$ & -0.0953 \\
Performance & 0.0308 & 0.0000 & 0.0000 & 0.0001 & 0.1827 \\
\hline
\end{tabular}

Dependent variable CGPA, coded ${ }^{*} \mathrm{p}<0.05$ 
Relationship between admission criteria \& academic performance

Table-II: Regression analysis for variables predicting academic performance. $(\mathrm{N}=197)$

\begin{tabular}{lccc}
\hline \multirow{2}{*}{ Predictor Variables } & \multicolumn{3}{c}{ Academic performance } \\
\cline { 2 - 4 } & Coefficient $(\beta)$ & $(95 C I)$ & P value \\
\hline Gender & -0.1642 & $(-0.3014,-0.0270)$ & 0.019 \\
Male* & & & \\
Female & -0.0181 & $(-0.3185,-0.0043)$ & 0.010 \\
Age at admission & 0.0127 & $(0.0063,0.019)$ & 0.000 \\
SSC Marks & 0.0327 & $(0.0242,0.0412)$ & 0.000 \\
Marks at diploma Nursing & 0.0052 & $(0.0019,0.0085)$ & 0.002 \\
Entry Test score & 0.0237 & $(0.0054,0.04197)$ & 0.011 \\
Experience & &
\end{tabular}

the time of admission recorded in years $(\beta=-0.018$, $p<0.019)$ and the gender being female $(\beta=-0.164$, $\mathrm{p}<0.001)$ were statistically significant negative predictors with the academic performance of the students.

\section{DISCUSSION}

The results of this study has shown a significant weak relationship between SSC marks and the academic performance $(\mathrm{r}=0.32, \mathrm{p}=<0.001)$ and also between the previous academic score at diploma nursing and the academic performance $(\mathrm{r}=0.48$, $p=<0.001)$. These results are consistent with previous research studies which support the notion that previous academic performance could predict subsequent academic performance of a student. 2,3,7-9

A significant but weak relationship $(\mathrm{r}=0.26$, $\mathrm{p}=<0.001$ ) was observed between academic performance and entry test score. However, previous academic score at diploma nursing level $(\beta=0.0327, p<0.001)$, SSC marks $(\beta=0.0127$, $\mathrm{p}<0.001)$, years of experience $(\beta=0.0237, \mathrm{p}<0.011)$ and entry test score $(\beta=0.005, p>0.002)$ were better predictor of a good academic performance of the post RN nursing students academic performance. The findings of this research study confirmed the relationship between admission entrance test and the academic performance as in the literature. ${ }^{10,11}$ However, there are other research studies that have shown either a poor or no predictive relationship between entrance tests and academic performance in health sciences students. In contrast to these findings, various researches have also shown no relationship between the aptitude test and initial academic performance. ${ }^{12}$ Entrance test alone is itself a weak predictor of the academic performance, however it can provide better screening if it is used jointly with other measures. ${ }^{10}$ Moreover, it is also suggested that an integrated approach may be used in the selection process with further researches. ${ }^{13,14}$

This study also shows a significant weak negative relationship $(r=-0.15, p=0.030)$ between age and the academic performance, whereas age is a negative predictor $(\beta=-0.018, p<0.019)$ of the academic performance. The result of this study is partly in contrast and partly in lined with other studies that old age is negatively co-related to academic performance. ${ }^{15,16}$ In addition to this, as age increases the academic performance may actually decline. Other research studies have also shown similar findings that younger students perform better than those who are old. ${ }^{17}$

This study shows a significant $(p<0.001)$ difference $(0.29)$ in the mean academic performance of males and females. This difference is statistically significant. A research study by Ali et al. reported that female gender is negatively co-related with academic performance. However, the co-relation is insignificant. ${ }^{7}$ In contrast to this, another research study has shown that the academic performance of females nursing students is higher than the male students. ${ }^{18}$ The regression analysis of this research study has shown that gender being female $(\beta=$ $-0.164, p<0.001)$ is negative predictors with the academic performance. However, research findings has revealed gender being female was a significant predictor of academic performance. ${ }^{18} \mathrm{In}$ addition to this, there are various research studies that have shown no significant difference in academic achievement between male an-d female students. ${ }^{19,20}$

\section{CONCLUSION}

The results of this study have shown significant relationship of various variables in the existing admission criteria with the academic performance that can be used to select nursing students who 
can be academically successful in future. Previous academic score at diploma nursing level, SSC marks, years of experience and entry test score were better predictor of the academic performance in nursing students. Moreover, the study concludes a significant relationship of academic performance with SSC marks, previous academic score at diploma nursing and entry test score. This study recommends using an integrated approach of selecting students for the post RN nursing program. However, different variables in the integration should be given weightage in accordance with the strength of relationship between the variables and the academic performances. The study may be replicated to other provinces and disciplines of health professions education programs so that a debate can be generated for rigorous admission criteria and changes in the current admission criteria.

\section{Grant Support E Financial Disclosures: None.}

\section{REFERENCES}

1. ValliJayanthi S, Balakrishnan S, Lim SiokChing A, Aaqilah Abdul Latiff N, Nasirudeen AMA. Factors Contributing to Academic Performance of Students in a Tertiary Institution in Singapore. Am J Educ Res. 2014;2:752-758. doi: 10.12691/education-2-9-8.

2. Burns SM. Predicting Academic Progression for Student Registered Nurse Anesthetists, AANA J. 2011;79(3):193-201.

3. Edward S. Reliability and Validity of Admissions Tools Used to Select Students for the Health Professions. Adv Health Sci Educ. 2001;6:159-175.

4. Brown L. An Exploratory Study of Predictors of Academic Success in a Graduate Nursing Program. Masters Theses 2011. Available at: https://scholarworks.gvsu.edu/cgi/ viewcontent.cgi? article $=1686 \&$ context $=$ theses

5. Bruce SL, Crawford E, Wilkerson GB, Rausch D, Dale RB, Harris M. Prediction Modeling for Academic Success in Professional Master's Athletic Training Programs. Athl Train Educ J. 2016;11:194-207. doi: 10.4085/1104194.

6. Mufti TS, Kifayatullah null, Qayum I. Rehman Medical College admission criteria as an indicator of students' performance in university professional examinations. J Ayub Med Coll Abbottabad. 2014;26:564-567.

7. Ali S, Haider Z, Munir F, Khan H, Ahmed A. Factors Contributing to the Students Academic Performance: A Case Study of Islamia University Sub-Campus. Am J Educ Res 2013;1:283-289. doi: 10.12691/education-1-8-3.

8. Fayolle A-V, Passirani C, Letertre E, Ramond A, Perrotin $\mathrm{D}$, Saint-Andre J-P, et al. [Predictive validity of selection process in medical school, a systematic review of the literature]. Press Med Paris Fr. 1983 2016;45:483-494. doi: 10.1016/j.lpm.2016.03.007.

9. Schripsema NR, van Trigt AM, Borleffs JCC, CohenSchotanus J. Selection and study performance: comparing three admission processes within one medical school. Med Educ. 2014;48:1201-1210. doi: 10.1111/medu.12537.
10. Tiffin PA, Mwandigha LM, Paton LW, Hesselgreaves $H$, McLachlan JC, Finn GM, et al. Predictive validity of the UKCAT for medical school undergraduate performance: a national prospective cohort study. BMC Med. 2016;14:140. doi: 10.1186/s12916-016-0682-7.

11. Mufti TS, Kifayatullah null, Qayum I. Rehman Medical College admission criteria as an indicator of students' performance in university professional examinations. J Ayub Med Coll Abbottabad. 2014;26:564-567.

12. Alhadlaq AM, Alshammari OF, Alsager SM, Neel KAF, Mohamed AG. Ability of admissions criteria to predict early academic performance among students of health science colleges at King Saud University, Saudi Arabia. J Dent Educ. 2015;79:665-670

13. Simpson PL, Scicluna HA, Jones PD, Cole AMD, O'Sullivan AJ, Harris PG, et al. Predictive validity of a new integrated selection process for medical school admission. BMC Med Educ. 2014;14:86. doi: 10.1186/1472-6920-14-86.

14. Mercer A, Abbott PV, Puddey IB. Relationship of selection criteria to subsequent academic performance in an Australian undergraduate dental school. Eur J Dent Educ 2013;17:39-45. doi: 10.1111/eje.12005.

15. Hayden LJ, Jeong SY, Norton CA. An Analysis of Factors Affecting Mature Age Students' Academic Success in Undergraduate Nursing Programs: A Critical Literature Review. Int J Nurs Educ Scholarsh. 2016;13:127-138. doi: 10.1515/ijnes-2015-0086.

16. Ali S, Haider Z, Munir F, Khan H, Ahmed A. Factors Contributing to the Students Academic Performance: A Case Study of Islamia University Sub-Campus. Am J Educ Res Am J Educ Res. 2013;1:283-289. doi: 10.12691/ education-1-8-3.

17. Adam J, Bore M, Childs R, Dunn J, Mckendree J, Munro D, et al. Predictors of professional behaviour and academic outcomes in a UK medical school: A longitudinal cohort study. Med Teach. 2015;37:868-880. doi: 10.3109/0142159X.2015.1009023.

18. Wan Chik WZ, Salamonson Y, Everett B, Ramjan LM, Attwood N, Weaver R, et al. Gender difference in academic performance of nursing students in a Malaysian university college. Int Nurs Rev. 2012;59:387-393. doi: 10.1111/j.14667657.2012.00989.x.

19. Lee S-J, Choi W, Kim SY, Choi J-W. Correlation of academic achievements with cognitive admission variables and demographics at chungbuk national university graduate medical school. Korean J Med Educ. 2009;21:59-66. doi: 10.3946/kjme.2009.21.1.59.

20. Faisal R, Shinwari L, Hussain SS. Academic performance of male in comparison with female undergraduate medical students in Pharmacology examinations. J Pak Med Assoc. 2017;67:204-208.

\section{Authors' Contribution:}

IIY: Conceived, Designed, Data collection and did statistical analysis \& manuscript writing.

BJ: Did review, Editing of manuscript and final approval of manuscript. 